\title{
Survei Permainan Tradisional dalam Pembelajaran Pendidikan Jasmani di Sekolah Dasar Se-Kecamatan Air Priukan Kabupaten Seluma
}

\section{T. P. Wibowo ${ }^{1, a)}$; E. Pranata ${ }^{1}$}

\section{Affiliation:}

1. Program Studi Pendidikan Jasmani FKIP UNIVED

Bengkulu

Corresponding Author:

a.

tito_wibowo99@yahoo.com

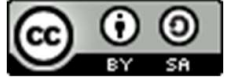

\section{Abstract}

The problem of this thesis is how the traditional game in Physical Education learning in each school in the Air Priukan Subdistrict. The purpose of this study is to find out the traditional game in Physical Education learning in each school. Air Priukan Subdistrict, Seluma District. Elementary School. The sampling technique used was the total sampling method, namely all elementary school physical education teachers throughout the Air Priukan Subdistrict, Seluma District, totaling 14 people from 14 elementary schools. The sampling technique uses random samples or random samples. Data collection in this study uses a survey method. Data collection techniques in this study are documentation and research. Documentation is used to obtain accurate data about the traditional game process in physical education learning in Primary Schools in Air Priukan Subdistrict, Seluma District. used is descriptive with percentages. 


\section{Pendahuluan}

Pendidikan merupakan suatu hal sangat penting bagi kehidupan bangsa dan kemajuan negara dengan adanya pendidikan bangsa Indonesia akan mengalami kemajuan dan meninggalkan keterpurukan. Pemerintah harus lebih berkonsentrasi terhadap pendidikan dan juga harus membuat suatu kebijakan yang mengarahkan pada perkembangan pendidikan di Indonesia. Pendidikan secara keseluruhan tidak akan terlepas dari pendidikan jasmani. Pendidikan jasmani pada hakikatnya adalah proses pendidikan yang memanfaatkan aktivitas fisik untuk menghasilkan perubahan dalam kualitas individu baik secara jasmani dan rohani sehingga pendidikan jasmani merupakan salah satu pendidikan yang sangat penting dan utama untuk kemajuan suatu bangsa.

Harapannya sekolah-sekolah dapat turut serta dalam melestarikan budaya Bangsa Indonesia melalui permainan tradisional, namun kenyataanya sampai saat ini permainan tradisional masih jarang bahkan tidak pernah dilakukan dalam pembelajaran penjasorkes, hal ini di sebabkan juga karena kurang nya sarana yang mendukung pelaksanaan permainan tradisional tersebut. Apabila guru penjasorkes tidak turut serta mengenalkan dan mengajarkan permainan tradisional kepada peserta didik, maka permainan tradisional yang berada di sekolah apabila tidak dilestarikan akan punah dan hilang.

\section{Metode Penelitian}

Penelitian ini adalah penelitian deskriptif kualitatif, artinya suatu penelitian yang digunakan untuk mengetahui keadaan yang sebenarnya berdasarkan hasil instrument angket yang valid dan reliabel dan dengan metode survei (Suharsimi Arikunto 2010:278). Metode yang digunakan untuk mengumpulkan data adalah metode survei. Instrumen yang digunakan adalah menggunakan angket. Populasi merupakan keseluruhan objek atau subjek yang berada pada suatu wilayah dan memenuhi syarat-syarat tertentu berkaitan dengan masalah penelitian,atau keseluruhan unit atau individu dalam ruang lingkup yang diteliti (Nanang Martono, 2012: 74). Populasi dalam penelitian ini yaitu seluruh guru penjasorkes di Sekolah Dasar Negeri seKecamatan Air Priukan Kabupaten Seluma Tahun 2020 sebanyak 14 responden.

Untuk pengambilan data yang sesuai dengan tujuan penelitian, peneliti terlebih dahulu memilih teknik pengumpulan data yang tepat. Adapun teknik pengumpulan data yang dilakukan :

1. Dokumentasi

Dokumentasi, berasal dari kata dokumen, yang artinya barang-barang tertulis.Dokumen sudah lama digunakan dalam penelitian sebagai sumber data karena dalam banyak hal dokumen sebagai sumber data dimanfaatkan untuk menguji, menafsirkan, bahkan untuk meramalkan (Moleong, 2011:217). Dokumen-dokumen bertujuan untuk mengumpulkan data yang berkaitan dengan objek penelitian serta dapat memperkuat dan melengkapi data yang telah diperoleh. Metode dokumentasi digunakan untuk memperoleh data yang akurat tentang proses permainan tradisional dalam pembelajaran pendidikan jasmani di Sekolah Dasar Negeri seKecamatan Air Priukan.

\section{Angket atau Kuesioner}

Kuesioner merupakan teknik pengumpulan data yang dilakukan dengan cara memberi seperangkat pertanyaan atau pernyataan tertulis kepada responden untuk dijawabnya. (Sugiyono, 2008:142). Kuesioner sebagai alat pengukur data penelitian dirumuskan dengan kriteria tertentu. Kuesioner yang dirumuskan tanpa kriteria yang jelas tidak banyak manfaatnya dilihat dari tujuan penelitian.Metode kuesioner ini digunakan sebagai alat pengumpul data tentang permainan tadisional dalam pembelajaran pendidikan jasmani.

\section{Hasil Penelitian dan Pembahasan}

Data yang diperoleh dalam penelitian ini disajikan dalam berbentuk persentase yang dibagi menjadi beberapa faktor, yaitu keterlaksanaan, alokasi waktu, perencanaan pembelajaran, dampak, dan faktor penghambat. Pernyataan yang diajukan sebanyak 26 butir pernyataan yang menggunakan 2 jawaban alternative "Ya" atau "Tidak" dengan skor "Ya=1" dan "Tidak=0".

Berikut ini adalah hasil analisis deskriptif survei permainan tradisional dalam pembelajaran pendidikan jasmani di Sekolah Dasar Negeri sekecamatan Air Priukan kabupaten Seluma tahun ajaran 2019/2020 yang terdiri 14 SD Negeri dengan 14 responden berdasarkan masing-masing faktor. 
1. Waktu

Berdasarkan tabel diatas dengan prosentase rata-rata sebesar $46,5 \%$ dan $53,5 \%$, dengan prosentase pernyataan no. $01,78 \%$ (Ya) dan $22 \%$ (Tidak) menunjukan bahwa waktu yang di akumulasikan untuk pembelajaran permainan tradisional sudah mencukupi, pernyataan no.2, 29\% (Ya) dan 71\% (Tidak), menunjukan bahwa banyak Sekolah Dasar yang tidak mempunyai jam tambahan untuk permainan tradisional, pernyataan no.3, 29\% (Ya) dan 71\% (Tidak) yang menunjukkan bahwa tidak di perlukan nya jam tambahan di luar jam yang sudah di tentukan untuk permainan tradisional, dan penyataan no.4, $50 \%$ (Ya) dan 50\% (Tidak), yang menunjukan bahwa setengah dari responden merasa dua kali pertemuan tatap muka sudah mencukupi untuk pembelajaran permainan tradisional, dan setengah dari responden merasa dua kali pertemuan tatap muka masih kurang untuk pembelajaran permainan tradisional.

Dari penjabaran di atas dapat di tarik kesimpulan bahwa waktu yang di akumulasikan untuk pembelajaran permainan tradisional di dalam pendidikan jasmani sudah mencukupi, dan juga tidak di perlukan nya jam tambahan di luar jam pembelajaran yang sudah di tentukan untuk permainan tradisional.

\section{Perencanaan}

Berdasarkan tabel di atas dengan prosentase rata-ratas sebesar $67,5 \%$ dan $32,5 \%$ dengan prosentase pernyataan no. 5, 50\% (Ya) dan $50 \%$ (tidak) yang menunjukan bahwa setengah dari responden hanya memberikan pembelajaran tentang permainan tradisional hanya di kelas bawah saja, dan setengah lagi dari responden juga memberikan pembelajaran tentang permainan tradisional di kelas atas juga. Dan pernyataan no. 6, 85\% (Ya) dan 15\% (Tidak), itu menunjukan berarti sebagian lebih dari responden membuat RPP tentang permainan tradisional, dan beberapa tidak membuatnya karena faktor tertentu.

Dapat di simpulkan dari penjabaran di atas bahwa permainan tradisional di terapkan di kelas bawah dan juga atas dan juga hampir seluruh responden menyiapkan RPP pembelajaran, namun ada juga responden yang tidak menyiapkan RPP pembelajaran karena faktor tertentu.

\section{Keterlaksanaan}

Dapat di lihat dari tabel prosentasi di atas yang menunjukan rata-rata $59 \%$ dan $40,69 \%$ dengan prosentase pernyataan no.7, 85\% (Ya) dan $15 \%$ (Tidak), yang berarti sebagian besar dari responden turut serta dalam pemenuhan sarana permainan tradisional, pernyataan no.8, 71\% (Ya) dan 29\% (Tidak) yang berarti bahwa sebagian besar sekolah memiliki sarana penunjang yang di perlukan untuk pembelajaran permainan tradisional,dan beberapa sekolah belum memiliki sarana penunjang yang di butuhkan untuk pembelajaran permainan tradisional di karenakan faktor tertentu, pernyataan no.9, 29\% (Ya) dan $71 \%$ (Tidak), yang menunjukan bahwa sarana penunjang yang ada di sebagian besar sekolah dalam kondisi yang sudah tidak baik lagi atau dalam keadaan rusak, pernyataan no.10, 29\% (Ya) dan $71 \%$ (tidak),yang berarti bahwa sarana penunjang yang ada di Sekolah masing sangat kurang dan masih sangat di perlukan untuk pemenuhan sarana permainan tradisional, pernyataan no. 11, 71\% (Ya) dan 29\% (Tidak) yang mengartikan bahwa sebagian besar sekolah yang ada sudah memiliki prasarana penunjang permainan tradisional, pernyataan no. $12,36 \%$ (Ya) dan 64\% (Tidak) berarti bahwa prasarana yang ada di sebagian besar sekolah dalam keadaan buruk atau tidak baik yang menimbulkan perasaan tidak nyaman saat bermain. Pernyataan no.13, $78 \%$ (Ya) dan 22\% (Tidak) ini berarti bahwa setengah lebih dari responden memberikan materi pembelajaran tentang egrang, pernyataan no. 14 $22 \%$ (Ya) dan 78\% (Tidak) ini berarti hampir sebagian besar responden tidak mengajarkan permainan gebuk bantal karna sarana dan prasarana yang tidak memungkinkan dan di nilai terlalu berbahaya untuk di laksanakan di usia anak Sekolah Dasar, pernyataan no. 15 100\% (Ya) dan $0 \%$ (Tidak) yang berarti bahwa seluruh responden mengajarkan permainan tarik tambang karna di nilai cukup aman untuk di mainkan anak usia sekolah dasar, pernyataan no.16, 71\% (Ya) dan $29 \%$ (Tidak) ini berarti sebagian responden mengajarkan permainan terompah panjang dan sedikit yang tidak karna faktor sarana yang tidak lengkap. Pernyataan no.17 100\% (Ya) dan 0\% (Tidak) yang berarti seluruh responden mengjarkan permainan haddang karna permainannya yang mudah dan sarana dan prasarana yang mudah di dapatkan. Pernyataan no.18, 50\% (Ya) dan 50\% (Tidak) ini berarti setengah dari responden ada yang mengajarkan permainan lari balok dan setengah nya tidak mengajarkan permainan lari balok karna faktor tertentu, pernyataan no,19 43\% (Ya) dan 57\% 
(Tidak) hal ini menunjukan bahwa hampir sebagian dari responden yang mengajarkan permainan patok lele, penyataan no.20, 85\% (Ya) dan $15 \%$ (Tidak) ini berarti sebgian besar responden mengajarkan permainan bentengan karna memang perminan ini mudah di mainkan dan tidak memerlukan banyak alat, pernyataan no 21, 15\% (Ya) dan 85\% (Tidak) hal ini berarti hampir sebagian besar responden tidak mengajarkan permainan sumpitan karna di nilai terlalu berbahaya bagi anak usia sekolah dasar, pernyataan no.22, 57\% (Ya) dan 43\% (Tidak) hampir senagian besar responden mengajarkan permainan dagongan akan tetapi dengan memodifikasi permainan tersebut, dan pernyataan no.23 43\% (Ya) dan 57\% Tidak hal ini bukan berarti responden tidak mengajarkan permainan gasing, di karenakan permainan gasing sendiri sudah sering di mainkan oleh anak-anak di luar sekolah.

Dapat di tarik kesimpulan dari penjabaran di atas bahwa dari kesebelas permainan tradisional yang ada hampir seluruhnya di mainkan di sekolah dasar, ada juga beberapa permainan yang tidak di mainkan di karenakan sarana yang kurang lengkap dan juga ada beberapa permainan yang menurut para responden terlalu berbahaya untuk di mainkan anak usia di sekolah dasar.

Dapat di tarik kesimpulan dari penjabaran di atas bahwa banyak sekolah yang belum memiliki sarana yang memadai dalam untuk permainan tradisional di dalam pembelajaran pendidikan jasmani, tentunya responden juga turut ikut serta dalam pemenuhan sarana permainan tradisional dalam pembelajaran pendidikan jasmani, bsnyak responden yang berharap adanya bantuan dari dinas terkait untuk pemenuhan sarana permainan tradisional. Dilihat dari penjabaran di atas bahwa hampir seluruh permainan tradisional yang sudah di bakukan oleh KOTI sudah di mainkan di sekolah namun ada juga permianan yang tidak di mainkan karena terlalu beresiko untuk di mainkan anak di usia sekolah dasar.

\section{Dampak}

Dapat di lihat dari tabel prosentasi di atas yang menunjukan rata-rata $75 \%$ dan $25 \%$ dengan pernyataan no.24, 100\% (Ya) dan 0\% (Tidak) hal ini berarti permainan tradisional sangat berpengaruh besar pada semangat belajar anak menurut para responden seluruh anak didik selalu bersemangat saat di ajak bermain permainan tradisional, hal ini menjadi alasan untuk beberapa responden menjadikan bebrapa permainan tradisional sebagai ganti pemanasan, kemudian pernyataan no.25, dengan prosen tase sebesar $50 \%$ (Ya) dan 50\% (Tidak) hal ini menunjukan bahwa sebagian responden memiliki pengalaman anak cidera pada saat memainkan permainan tradisional, hal ini kadang terjadi karna kelalaian pengawasan atau miss komunikasi sehingga terjadinya kecelakaan kecil seperti anak bertabrakan saat berlari bermain bentengan dan terjatuh saat berlari.

Dari penjabaran di atas dapat di simpulkan bahwa permainan tradisional memiliki dampak positif yang sangat besar yaitu menumbuhkan semngat para pesrta didik saat ada di dalam pembelajaran pendidikan jasmani, namun permainan tradisional bisa juga memiliki dampak negatif ketika dalam pelaksanaan nya terjadi kelalaian dalam pengawasan atau terjadi miss komunikasi.

\section{Faktor penghambat}

Dapat di lihat dari tabel prosentasi yang ada di atas yang menunjukan rata-rata $8 \%$ dan $92 \%$ dengan pernyataan no.26, 8\% (Ya) dan 92\% (tidak) hal ini menunjukan bahwa hampir seluruh responden tidak merasa kesulitan saat menyampaikan materi permainan tradisional.

\section{Kesimpulan}

Berdasarkan penelitian dan pembahasan dapat diambil simpulan bahwa permainan tradisional dalam pembelajaran pendidikan jasmani di setiap Sekolah Dasar Se-Kecamatan Air Priukan Kabupaten Seluma sudah dilaksanakan dengan baik. Namun masih ada keterbatasan sarana permainan tradisional, di setiap sekolah hal ini tentu saja mempengaruhi keterlaksanaan permainan tradisional dalam pembelajaran pendidikan jasmani di Sekolah Dasar Negeri seKecamatan Air Priukan Kabupaten Seluma.

\section{Daftar Pustaka}

BSNP. 2006. Standar kompetensi dan kompetensi dasar sekolah dasar dan madrasah ibtidaiyah. Jakarta: Badan Standar Nasional Pendidikan.

Depdiknas. 2013. Kurikulum 2013.

Hamalik,Oemar. 2008. Kurikulum dan pembelajaran. Jakarta: PT. Bumi Aksara

Husain, F.A. 2013. "Survei pemahaman permainan tradisional dalampembelajaran penjasorkes pada siswa di sekolah dasar sekecamatan brangsong kabupaten kendal". Skripsi S1. Laporan Penelitian. FIK UNES: 
Semarang.

Ibrahim, Rusli,dkk. 2008. Psikologi olahraga, Bandung : FPOK UPI.

Kurniati,Euis. 2016. Permainan tradisional dan perannya dalam mengembangkan ketrampilan sosial anak. Jakarta :Prenadamedia Group

Lutan,Rusli, 2001, Mengajar pendidikan jasmani, pendekatan pendidikan gerak

sekolah dasar, Depdiknas

Rukmana, Anin. 2008. Pembelajaran pendidikan jasmani di sekolah dasar(Jurnal) Sumedang: UPI Kampus Sumedang

Rusman. 2010. Model-model pembelajaran. Jakarta: Raja Grafindo Persada.

Soemitro. 1992. Permainan kecil. Jakarta: Depdikbud. 